\title{
DAKWAH VIA JURNALISTIK RADIO
}

\author{
Oleh: M. Yose Rizal Saragih
}

\begin{abstract}
Abtrak
Tulisan ini menguraikan kelebihan media radio sebagai media dakwah karena siaran radio tidak mengenal ruang dan waktu serta jangkauan luas yang cenderung tidak terbatasi apapun. Menjadikan jurnalistik radio sebagai bagian dakwah penting karena pesan dakwah dapat disampaikan ke seluruh khalayak dengan hanya mendengar dengan tujuan untuk perbaikan dan pembangunan mental spiritual sebagaimana tujuan utama dakwah. Dakwah via jurnalistik radio ini tentu saja berkaitan dengan posisi radio yang sampai saat ini terus bertahan dan cenderung berkembang mengikuti segala perubahan yang terjadi, maka menjadikan jurnalistik radio sebagai media dakwah merupakan bagian dari aktualisasi dakwah dalam kehidupan kontemporer.
\end{abstract}

Kata Kunci: Dakwah, Jurnalistik Radio dan Komunikasi

\section{Pendahuluan}

Berangkat dari perintah melaksanakan dakwah, maka terilhamilah berbagai bentuk starategi dengan memanfaatkan teknologi khususnya tekhnologi penyiaran dalam hal ini radio. Dengan melihat berbagai kelebihannya dan fungsinya, mutlak bagai para dai untuk menggunakan radio sebagai media strategi didalam menyampaikan pesan dakwahnya ditengah khalayak. Selanjutnya pada pembahasan, kita akan coba paparkan pengantar singkat tentang sejarah ringkas radio, pengertiannya, radio sebagai media dakwah, 
efektivitas dakwah melalui radio. Tulisan ini dimaksudkan untuk memanfaatkan jurnalistik radio sebagai bagian dari media dakwah.

\section{Sekilas Sejarah Jurnalistik Radio}

Dasar teori dari perambatan gelombang elektromagnetik pertama kali dijelaskan pada tahun 1873 oleh James Clerk Maxwell dalam papernya di Royal Society mengenai teori dinamika medan elektromagnetik berdasarkan hasil kerja penelitian yang dikerjakan antara tahun 1861 dan 1865. Untuk pertama kalinya, Henirich Rudolf Hertz membuktikan teori Maxwell itu antara tahun 1886 dan I888, melalui eksperimen dia berhasil membuktikan radiasi gelombang radio memiliki sifat-sifat gelombang (sekarang disebut gelombang heizan), dan menemukan bahwa persamaan elektromagnetik dapat diformulasikan ke dalam persamaan gelombang.

Kehadiran radio di Indonesia sudah ada sejak zaman pendudukan Belanda yang ditandai dengan berdirinya Batavia Radio Vereneging (RRV) pada tanggal 16 Juni 1925 . Selanjutnya, berdirilah berbagai macam stasiun radio seperti di Jakarta, Bandung, Surakarta, Medan dan daerah lainnya. Demikian juga halnya ketika zaman Jepang berbagai stasiun radio diambil alih oleh Jepang yang diurusoleh jawatan khusus yang bernama hoso kanri kyoku. ${ }^{1}$

Radio memang Memiliki banyak kelebihan, memiliki kesederhanaan bentuk (Portability) dan kemampuan yang tinggi untuk menjangkau setiap pendengarnya yang sedang melakukan kegiatan-kegiatan lainnya. Bitner mencatat bahwa pada tahun 1977 saja di Amerika dengan 10.000 stasiun pemancar radio mampu menembus kehidupan hampir seluruh penduduk dunia. Kenyataan tersebut tentu saja tidak tiba-tiba terjadi. Di Italia berawal dari sebuah eksperimen yang dilakukan oleh Guglielmo Marconi pada tahun 1895, dengan menggunakan transmisi yang cukup sederhana ia dapat menyampaikan signal disepanjang pinggiran perbukitan dekat rumahnya. Tidak lama sesudah itu, Marconi mampu merebut perhatian dunia dengan menyampaikan dan menerima signal melintas Atlantik tanpa melalui sambungan kabel.Saat itu apa yang dikerjakan Marconi tentunya membuat orang kaget. Sejak itu seperti dijelaskan oleh Francis pada tahun 1901 penemuan tersebut

${ }^{1}$ T. A. Latief Rousydy, Dasar-dasar Rhetorika Kamunikasi dan Informasi (Medan: Firma Rimbow, 1989), h.176. 
mulai digunakan sebagai komunikasiangkatan laut Amerikauntukmenghubungkan antar kapal yang sedang berlayar dengan sejumlah stasiun di darat. ${ }^{2}$

Pada era teknologi berikutnya radio hanya berfungsi untuk menyiarkan musik dan berita kepada masyarakat. Tahun 1909, Charles David Herrold mengudara lewat stasiun miliknya sendiri di San Jose dan pada tahun 1981 sebuah siaran di University of Wisconsin muncul untuk pertama kalinya sebagai radio nasional non-komersial. Kini sejalan dengan perkembangan teknologi komunikasi informasi, radio terus berkembang serta mampu mempertahankan posisinya sebagai the fifth estate (kekuatan kelima) setelah pers dalam tatanan kehidupan sosial. ${ }^{3}$ Bedanya dengan surat kabar,majalah dan buku,radio merupakan media massa yang bersifat visual, yaitu hanya dapat didengar. Karenanya radio tidak seperti media massa cetak yang dapat dibaca Ulang.

Ditinjau dari aspek komunikasi massa, keberadaan radio sama dengan pers.Para ahli Komunikasi berpendapat bahwa yang dimaksud dengan komunikasi massa (mass communication) adalah komunikasi melalui media massa, fungsi komunikasi massa tidak berbeda dengan fungsi pers, dan media massa sering disebut juga dengan pers. ${ }^{4}$ Oleh karenanya radio sebagai salah satu bagian dari komunikasi masa menurut Onong Uchjana Efendi ada empat: (1) menyampaikan informasi (to inform) (2) Mendidik (to educate) (3) menghibur (to entertain), dan (4) mempengaruhi (to influence) dan selain dari fungsi tersebut para ahli juga menambahkan adanya fungsi membimbing (to gaide) serta fungsi mengkritik (to criticise). ${ }^{5}$

Fungsi pers pada radio ditengah-tengah masyarakat pada setiap penyiaran dapat memberikan informasi yang beraneka ragam kepada khalayak ramai (massa). Disamping itu juga dapat memberikan pendidikan kritik yang bersifat membangun dan berguna bagi masyarakat luas dan audience. Fungsi lainnya juga adalah dapat mempengaruhi pendapat umum

${ }^{2}$ Asep Saeful Muhtadi, Jurnalistik: Pendekatan Teori dan Praktek (Jakarta: Logos Wacana Ilmu, 1999), h. 96-97.

${ }^{3}$ Ibid., h. 97.

${ }^{4}$ Ainur Rofiq Sophiaan, Tantangan Media Informasi Islam: antara Profesionalisme dan Dominasi Zionis (Surabaya: Risalah Gusti, 1993), h. 23.

${ }^{5}$ Onong Uchyana Effendy, Dinamika Komunikasi (Bandung: Penerbit Aditya Bakti, 1986), h. 31 . 
(public opinion). Sebagai penghubung atau menjembatani (to bridge) antara masyarakat dengan pemerintah atau sebaliknya.Komunikasi-komunikasi yang tidak dapat tersalurkan melalui jalur atau kelembagaan yang ada,bisa disampaikan melalui pers. Demikian juga aspek hiburan yang disajikan radio, bukan hanya sekedar memberikan hiburan kepada masyarakat, tetapi dalam pengertian (massa). Disamping itu juga dapat memberikan pendidikan, kritik yang hersifat membangun dan berguna bagi masyarakat luas atau audience. Fungsi lainnya juga adalah dapat mempengaruhi pendapat umum (publik opinion), sebagai menghubung atau menjembatani (to hridge) antara masyarakat dengan pemerintahatau sebaliknya. Komunikasi-komunikasi yang tidak dapat tersalurkan melalui jalur atau kelembagaan yang ada, bisa disampaikan melalui pers. Demikian juga aspek hiburan yang disajikan radio, bukan hanya sekedar memberikan hiburan kepada masyarakat, tetapi dalam pengertian bisa memberikan kepuasan-kepuasan, kesenangankesenangan, keberhasilan dan sebagainya. ${ }^{6}$

Dalam menjalankan fungsinya tersebut, radio harus selalu memperhatikan mana informasi yang layak dikomunikasikan dan mana pula yang tidak pantas dikomunikasikan. Kelayakan menyampaikan komunikasi melalui radio tersebut sangat ditentukan oleh nilai-nilai yang dianut oleh suatu kelompok masyarakat. Dalam Islam, tentunya tata nilai yang dijadikan ukuran adalah ajarannya.

Tugas berat yang harus dilakukan radio sebagai salah satu media kornunikasi massa adalah menjalankan fungsi kontrol (social control) Dalam hal pekerja radio (reporter) dituntut memiliki keberanian (jihad) dalam rangka menegakkan kebenaran dan keadilan, Bila tidak melakukän kontrol sosial, maka fungsinya sebagai media komunikasi massa tidak berjalan efektif untuk itulah arah reporter dituntut untuk berpengetahuan luas, bertanggung jawah sosial, inters berbagai aspek kehidupan, ulet dan tekun dan patuh pada kode etik. ${ }^{7}$

Radio secara umum dalam kehidupan sehari-hari digunakan sebagai penyampaian informasi. Suara yang kita dengar dan pesawat radio merupakan

6Widodo, Teknik Wartawan Menulis Berita di Surat Kabardan Majalah (Surabaya: Penerbit Indah, 1997), h. 7-8.

${ }^{7}$ Ibid., h. 82-83 
perubahan bentuk energi elektromagnetik dan gelombang radio yang ditangkap oleh pesawat radio, kemudian diubah melalui loudspeaker (pengeras suara) menjadi energi bunyi sehingga bisa kita dengar. Suara yang kita dengar daripesawat radio biasa berisi tentang hiburan, misalnyamusik, humor serta berita dan berbagai informasi lainnya. Jadi penyebutan istilah radio pada umumnya rancu. Pengertian pertama adalah alat atau pesawat untuk mengubah gelombang radio menjadi gelombang bunyi atau suara. Sedangkan pengertian lainnya ialah gelombang radio yang merupakan bagian dan gelombang elektromagnetik.

\section{Radio sebagai Media Dakwah}

Kata radio menurut ensiklopedi Indonesia yaitu penyampaian informasi dengan pemanfaatan gelombang elektromagnetik bebas yang memiliki frekuensi kurang dari $300 \mathrm{GHz}$ (panjang gelombang lebih besar dari $1 \mathrm{~mm}$ ). Sedangkan istilah "radio siaran" atau "siaran radio" berasal dan kata "radio broadcast" (Inggris) atau "radio omroep" (Belanda) artinya yaitu penyampaian, informasi kepada khalayak berupa suara yang berjalan satu arah dengan memanfaatkan gelombang radio sebagai media. Sedangkan menurut versi Undang-undang Penyiaran No 32/2002 : kegiatan pemancarluasan siaran melalui sarana pemancaran dan/atau sarana transmisi di darat, di laut atau di antariksa dengan menggunakan spektrum frekwensi radio melalui udara, kabel, dan/atau media lainnya untuk dapat diterima secara serentak dan bersamaan oleh masyarakat dengan perangkat penerima siaran, yang dilakukan secara teratur dan berkesinambungan. ${ }^{8}$

Keuntungan dari radio ialah dapat menjangkau hampir seluruh Negara dalam lapisan masyarakat setiap waktu, setiap tempat dan melibatkan siapa saja (bahkan orang buta huruf) serta dimana saja. Pendengar radio tidak harus tetap berada didepan pesawat radionya, tidak seperti halnya menonton televisi. Ini berarti mendengarkan radio dapat dilakukan sembari melakukan hal-hal lainnya, berpindah tempat, tetapi harus dengan konsentrasi tinggi. Berarti lebih banyak waktu yang dapat digunakan untuk mengerjakan hal-hal lainnya, sambil dapat mendengarkan atau menikmati suara radio.

8Samsul Wahidin, Filter Komunikasi Media Elektronik (Banjarmasin: Komisi Penyiaran Indonesia Daerah Kalimantan Selatan, 2006), h. 29. 
Ini juga berarti bahwa makin banyak pendengar yang dapat dijangkau sementara mereka masih tetap dapat bekerja sesuai tanggung jawab pekerjaannya.

Radio adalah media elektronik termurah, baik pemancar maupun penerimanya. Ini berarti terdapat ruang untuk lebih banyak stasiun radio dan lebih banyak pesawat penerima dalam sebuah perekonomian nasional. Dibandingkan dengan media lain, biaya yang rendah sama artinya dengan akses kepada pendengar yang lebih besar danjangkauan lebih luas kepada kaum dengan tingkat ekonomi yang rendah.

Radio merupakan salah satu di antara alat komunikasi massa. Seperti media massa lain, radiopun mempunyai fungsi sebagai alat pemberi informasi. Lewat radio, seseorang dapat mengetahui dan memahami sesuatu. Sebagai alat yang mendidik muatan sajiannya dapat meningkatkan pengetahuan, keterampilan, moral dan akhlak seseorang. Sebagai alat penghibur, siaran radio dapat membuat seseorang terhibur, senang, memenuhi hobi, dan mengisi waktu luang.

Karena radio sebagai media, muatan-muatan agama tak harus hadir secara normatif, tapi lewat pendekatan sosiologis dan psikologis agar "menyentuh" para pendengar. Format acara agama dapat berupa ceramah, dialog, fragmen, langen suara, feature majalah udara, uraian, diskusi, dialog interaktifdan radio spot/skide audio. Kelebihan media radio sebagai media dakwah adalah:

a. Bersifat langsung

Untuk menyampaikan dakwah melalui radio. Tidak harus melalui proses yang kompleksebagaimana penyampaian materi dakwah lewat pers, majalah umpamanya. Dengan mempersiapkan secarik kertas, da'i dapat secara langsung menyampaikan dakwah di depan mikrofon.

b. Siaran radio tidak mengenal jarak dan rintangan

Faktor lain yang menyebabkan radio dianggap memiliki kekuasaan ialah bahwa, radio tidak mengenal jarak dan rintangan selain waktu, ruang pun bagi radio siaran tidak merupakan masalah, bagaimanapun jauhnya sasaran yang dituju di atasi dengan mediaini.

c. Radio siaran mempunyai daya tarikyang kuat

Faktor lainnya yang menyebabkan radio memiliki kekuasaan adalah daya tarikyang kuat yang dimilikinya. Daya tarik ini disebabkan karena 
sifatnya yang serba hidup berkait tiga unsur yakni musik, kata-kata, dan efek suara.

d. Biaya yang relatif murah

Di banyak negara di dunia ketiga Asia, dan Amerika latin, radio umumnya telah menjadi media utama yang dimiliki setiap penduduk, baik yang kaya maupun yang miskin.

e. Mampu menjangkau tempat-tempat terpencil.

Di beberapa negara, radio bahkan merupakan satu-satunya alat komunikasi yang efektif untuk menghubungi tempat-tempat terpencil.

f. Tidak terhambat oleh kemampuan baca dan tulis.

Di samping keuntungan-keuntungan di atas radio juga memiliki keuntungan lain.Siaran radio tidak terhambat oleh kemampuan baca dan tulis khalayak. Di beberapa Negara Asia tingkat kemampuan baca dan tulis populasinya lebih dari $60 \%$ jutaan orang tersebut tidak disentuh oleh media massa lain kecuali bahasa dalam bahasa radio dalam bahasa mereka. ${ }^{9}$

\section{Efektivitas Dakwah via Radio}

Islam adalah agama dakwah karena setiap umat Islam yang telah akil baligh wajib berdakwah sesuai dengan kemampuan masing-masing (Q.S. al-Nahl[16]: 125), yang artinya "serulah (manusia) kejalan Tuhanmu dengan hikmah dan pelajaran yang baik. Sesungguhnya Tuhan-mu, dialah yang lebih mengetahui tentang siapa-siapa yang tersesat dari jalan-Nya dan dialah yang lebih mengetahui orang-orang yang mendapat petunjuk". Dakwah itu juga mestilah dilaksanakan secara bijaksana sesuai dengan keadaan dan perkembangan zaman. Dalam melaksanakan dakwah harus hasil kemajuan sains dan teknologi komunikasi modern demi untuk mencapai hasil yang lebih baik.

Radio sebagai salah satu media komunikasi massa yang sangat efektif dalam menyampaikan informasi apapun yang sedang terjadi dimana saja, selain itu juga radio memiliki fungsi khusus yakni dalam aktivitas dakwah Islam yakni sebagai media dalam menyampaikan pesan-pesan dakwah

${ }^{9}$ Effendy, Dinamika Komunikasi, h. 32. 
Islam kepada khalayak pendengar dalam upaya perbaikan dan pembangunan mental spiritual umat Muslim. Fungsi radio dapat dijelaskan sebagai berikut:

\section{a. Fungsi Menyiarkan Informasi}

Fungsi pertama adalah menyajikan berbagai macam informasi mengenai berbagai hal termasuk di dalamnya informasi tentang kelslaman, peristiwa yang terjadi, gagasan atau pikiran cendekiawan, apa yang dikatakan, diperbuat, dilihat orang lain dan lain-lain sebagainya yang mengandung unsur dakwah Islam. Fungsi menyampaikan informasi bernadakan dakwah Islam ini bisa secara implisit dalam bentuk berita-berita dunia Islam, ceramah agama dakwah Islam, baik bersifat rutin maupun tidak.

\section{b. Fungsi Mendidik}

Radio dapat membuat acara-acara yang mengandung aspek pendidikan dan pengetahuan agama, sehingga khalayak pendengar aktif mengikutinya dan bertambah ilmu pengetahuan agamanya. Fungsi mendidik ini bagi radio dalam aktifitas dakwah Islam adalah menyampaikan pesan-pesan keIslaman yang bersifat mendidik umat, agar nilai-nilai Islam itu dapat terintegrasi dalam diri individu dan masyarakat penganutnya sehingga menjadi umat Islam yang bertakwa kepada Allah. Fungsi mendidik ini dalam kegiatan dakwah Islam dalam siaran khusus dakwah Islam, sandiwara-sandiwara keislaman yang kadang-kadang mengandung aspek kehidupan.

\section{c. Fungsi Menghibur}

Hal-hal yang bersifat bernadakan keIslaman dapat juga dimuat dalam siaran radio. Isi siaran radio yang bersifat hiburan yang bernadakan dakwah keIslaman bisa berbentuk lagu-lagu, sandiwara-sandiwara juga berita yang mengandung minat insani (human interest) dan kadang-kadang tajuk rencana. Pemuatan isi siaran radio yang bersifat hiburan yang mengandung unsur dakwah tersebut selain untuk menghilangkan ketegangan pikiran setelah para pendengar dihidangi siaran dan berita yang serius misalnya tentang politik, juga para pengelola radio dapat menyelipkan pesan-pesan dakwah Islam kepada para pendengar setianya, baik secara langsung maupun tidak langsung. Misalnya, membaca kutipan sebuah hadis maupun 
pepatah para pejuang Islam yang kiranya bisa memberikan nasehatnasehat kepada pendengar radio.

\section{d. Fungsi Mempengaruhi}

Fungsi mempengaruhi yang melekat pada radio dalam aktivitas dakwah Islam pada hakekatnya adalah mempengaruhi para pembaca secara sadar supaya mereka meyakini menghayati dan mengamalkan ajaran Islam dalam kehidupan sehari-hari. Fungsi mempengaruhi ini secara eksplisit terdapat pada berita-berita keagamaan yang disajikannya, misalnya pemuatan berita tentang suasana pelaksana ibadah haji umat Islam ke Mekah maupun Madina beserta laporan lengkapnya yang memuat pada siaran pertama radio. Hal tersebut sedikit banyaknya akan mempengaruhi para pendengar, khususnya kaum Muslimin. Kemudian siaran tentang pernyataan para alim ulama atau tokoh agama mengenai suatu masalah yang menyangkut kepentingan umat Islam yang dimuat pada halaman pertama radio juga akan mempengaruhi pembaca.

Sedangkan secara implisit terdapat pada siaran khusus keagamaan kajian tafsir, mimbar jumat, ruang konsultasi agama dan lain-lain. Ada juga mengandung unsur dakwah Islam yang pada umumnya berisi opini dan penceramah. Demikianlah fungsi radio dalam aktifitas dakwah Islam yang pada hakekatnya tidak pernah lekang dari peristiwa-peristiwa dan hal-hal lainnya yang menyangkut kepentingan umat Islam. Apabila fungsi radio dalam aktivitas dakwah Islam yang pada hakekatnya tidak pernah lekang dari peristiwa-peristiwa dan hal-hal lainnya yang menyangkut kepentingan umat Islam. Apabila para pengelola radio dan para penyiar Islam dapat memanfaatkan radio sebagai salah satu media dakwah Islam, maka keberadaan radio akan semakin bertambah penting bagi umat Islam. Selain sebagai agen informasi, radio juga sebagai motivator (pemberi semangat) bagi pembangunan umat Islam. Akan tetapi, kenyataan yang kita sukseskan saat sekarang ini ialah masih sedikit umat Islam yang memanfaatkannya. ${ }^{10}$

${ }^{10}$ Agustoha Kuswata, et.al., Komunikasi Islam dari Zaman ke Zaman (Jakarta: Arikha Media Cipta, 1990), h. 21. 


\section{PENUTUP}

Radio di Indonesia sudah ada sejak zaman pendudukan Belanda yang ditandai dengan berdinnya Batavia Radio Vereneging (RRV) pada tanggal 16 Juni 1925 selanjutnya berdirilah berbagai macam stasiun radio seperti di Jakarta, Bandung, Surakarta, Medan dan daerah lainnya. Demikian juga halnya ketika zaman Jepang berbagai stasiun radio diambil alih oleh Jepang yang diurusoleh jawatan khusus yang bernama Hoso Kanri Kyoku. Istilah "radio siaran" atau "siaran radio" berasal dan kata "radio broadcast" (Inggris) atau "radio omroep" (Belanda) artinya yaitu penyampaian, informasi kepada khalayak berupa suara yang berjalan satu arah dengan memanfaatkan gelombang radio sebagai media.

Kelebihan media radio sebagai media dakwah adalah bersifat langsung, siaran radio tidak mengenai jarak dan rintangan, Radio siaran mempunyai daya tarik yang kuat, Biaya yang relative murah, Mampu menjangkau tempattempat terpencil, Tidak terhambat oleh kemampuan baca dan tulis. Pesan dakwah Islam kepada khalayak pendengar dalam upaya perbaikan dan pembangunan mental spiritual umat muslim, dapat di sinergiskan dengan memanfaatkan dari fungsi radio tersebut, antara lain fungsi menyiarkan informasi, fungsi mendidik, fungsi menghibur dan fungsi mempengaruhi. 


\section{DAFTAR PUSTAKA}

Effendy, Onong Uchyana, Dinamika Komunikasi (Bandung: Penerbit Aditya Bakti, 1986).

Kuswata, Agustoha, et.al., Komunikasi Islam dari Zaman ke Zaman (Jakarta: Arikha Media Cipta, 1990).

Muhtadi, Asep Saeful, Jurnalistik: Pendekatan Teori dan Praktek (Jakarta: Logos Wacana Ilmu, 1999).

Rousydy, T. A. Latief, Dasar-dasar Rhetorika Kamunikasi dan Informasi (Medan: Firma Rimbow, 1989).

Sophiaan, Ainur Rofiq, Tantangan Media Informasi Islam: antara Profesionalisme dan Dominasi Zionis (Surabaya: Risalah Gusti, 1993).

Wahidin, Samsul, Filter Komunikasi Media Elektronik (Banjarmasin: Komisi Penyiaran Indonesia Daerah Kalimantan Selatan, 2006).

Widodo, Teknik Wartawan Menulis Berita di Surat Kabar dan Majalah (Surabaya: Penerbit Indah, 1997). 